\title{
Pregnancy resulting from cattle oocytes matured and fertilized in vitro
}

\author{
K. P. Xu, T. Greve, H. Callesen and P. Hyttel* \\ Departments of Animal Reproduction and*Anatomy, Royal Veterinary and Agricultural University, \\ Bülowsvej 13, DK-1870 Frederiksberg C, Denmark
}

\begin{abstract}
Summary. Follicular oocytes $(n=81)$ collected from cattle at a local slaughterhouse were matured and fertilized in vitro. Of 27 ova $19(70 \%)$ were penetrated by spermatozoa and 40/54 (74\%) inseminated ova transferred surgically to the oviducts of a synchronized heifer were recovered by non-surgical flushing of the uterine horns 6 days later. Of the 40 ova $15(38 \%)$ were at the morula, early blastocyst or diminutive morula stages. Culture in vitro sustained further development of all embryos and 9 were expanding or expanded blastocysts. One pregnancy resulted from non-surgical transfer of 2 blastocysts. The results demonstrate that immature oocytes from cattle can be matured and fertilized in vitro, subsequently develop to the blastocyst stage, and develop into a normal pregnancy after non-surgical transfer.
\end{abstract}

\section{Introduction}

All calves born after in-vitro fertilization have originated from in-vivo matured oocytes transferred surgically to the oviduct of synchronized recipients (Brackett et al., 1982) or following incubation in rabbit or sheep oviducts (Sirard \& Lambert, 1986). In-vitro fertilization of in-vitro matured oocytes has only resulted in the formation of early embryonic stages (Ball et al., 1983). However, Critser et al. (1986) and K. H. Lu (personal communication) have obtained pregnancies resulting from in-vitro matured oocytes fertilized in vitro, cultured in ligated sheep oviducts and subsequently transferred to the final recipient heifer. Like Brackett et al. (1982) we have established pregnancies by transferring in-vivo matured and in-vitro fertilized oocytes to the oviducts of recipient heifers (Greve et al., 1987). Here we present a study in cattle in which morulae/blastocyts and a pregnancy were obtained from slaughterhouse oocytes that were matured and fertilized in vitro, cultured 6 days in heifer oviducts and upon non-surgical recovery transferred non-surgically to a final recipient heifer.

\section{Materials and Methods}

Oocytes were collected fron 10 heifers/cows at an unknown stage of the reproductive cycle at a local slaughterhouse by aspiration from small antral follicles (1-6 mm in diameter) within $30 \mathrm{~min}$ after slaughter. The aspirates were placed in tubes containing 4-5 ml Hepes-buffered Ham's F-10 medium (Flow Laboratories, Irvine, U.K.), supplemented with $20 \%$ heat-inactivated cow's serum (collected on the day of standing oestrus), $0.4 \mathrm{~mm}$-glutamine, 50 i.u. penicillin $/ \mathrm{ml}$ and $50 \mu \mathrm{g}$ streptomycin $/ \mathrm{ml}$. Ovaries were collected and kept in a vacuum flask together with the tubes at $32-38^{\circ} \mathrm{C}$ during collection and transportation to the laboratory.

From the sediments at the bottom of the tubes 81 oocytes with compact cumulus layers (Fig. 1) were recovered and washed three times in the oocyte maturation medium, which was identical to the medium mentioned above except that bicarbonate buffer replaced Hepes. Granulosa cells were obtained by dissection of small follicles and subsequent perfusion of the follicular cavity with medium. There was no attempt to recover the oocytes of these follicles. The recovered granulosa cells were washed and added to the oocyte maturation medium to give an approximate concentration of $3 \times 10^{6} / \mathrm{ml}$. Oocytes were cultured for $27 \mathrm{~h}$ in 4-well multidishes (Nunc, Roskilde, Denmark) with $10-15$ oocytes $/ 1.0 \mathrm{ml} \mathrm{medium} /$ well in an incubator with $5 \% \mathrm{CO}_{2} /$ air at $38^{\circ} \mathrm{C}$ with $100 \%$ humidity in order to achieve complete maturation. 

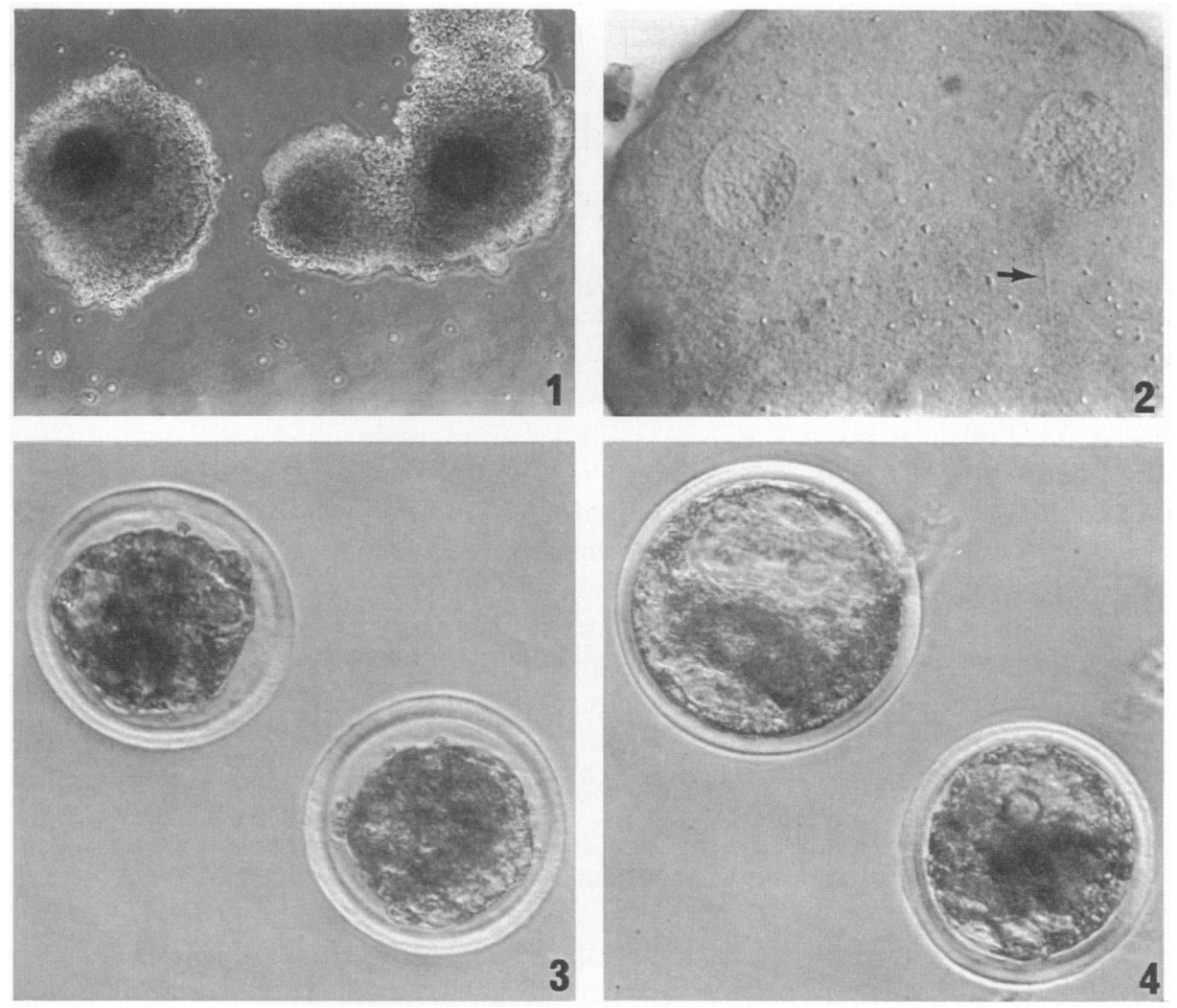

Fig. 1. Oocytes before maturation. $\times 70$.

Fig. 2. A penetrated ovum, showing a male pronucleus on the right with sperm tail (arrow) and a female pronucleus on the left. $\times 300$.

Fig. 3. Two early blastocysts cultured for $4 \mathrm{~h}$, which were at the morula stage at recovery. $\times 180$.

Fig. 4. One blastocyst and one expanded blastocyst cultured for $20 \mathrm{~h}$, which were at the morula stage at recovery. $\times 180$.

Semen was obtained and spermatozoa processed by the method previously described by Parrish et al. (1986) and Greve et al. (1987). Briefly, frozen semen samples from two bulls of known fertility were thawed and washed in modified Tyrode's solution. The motile sperm fraction was obtained by a swim-up separation procedure, and then treated with $\sim 10 \mu \mathrm{g}$ heparin $/ \mathrm{ml}$ (Sigma, St Louis, MO, U.S.A.) for $15 \mathrm{~min}$.

Oocytes matured in vitro were treated with $0.1 \%$ hyaluronidase (Sigma) to remove part of the cumulus cells. Five oocytes were placed in each $50 \mu$ l Tyrode's medium droplet covered with paraffin oil. Spermatozoa were added to reach a concentration of $\sim 0.5 \times 10^{6} / \mathrm{ml}$. The sperm-oocyte co-culture conditions were identical to those for oocyte maturation except for the temperature, which was at $39^{\circ} \mathrm{C}$.

After $22 \mathrm{~h}$ of co-culture, 54 ova were washed to remove most of the cumulus cells and the attached spermatozoa before transfer to the intermediate recipient. The remaining 27 ova were fixed $24 \mathrm{~h}$ after insemination in methanol: acetic acid $(3: 1, \mathrm{v} / \mathrm{v})$ for $48 \mathrm{~h}$ and then stained with $1 \%$ aceto-orcein for microscopic evaluation of sperm penetration.

The intermediate recipient heifer was synchronized by an injection of $0.675 \mathrm{mg}$ cloprostenol $(2.5 \mathrm{ml}$ Estrumat Vet.: H. Lundbeck \& Co. A/S, Copenhagen, Denmark) $89 \mathrm{~h}$ before receiving ova by transfer to the oviducts through a midline incision under general anaesthesia as previously described by Greve et al. (1987) and Hyttel et al. (1988).

The uterus of the animal was flushed non-surgically 6 days after transfer. The recovered ova were further cultured in Ham's F-10 medium supplemented with $20 \%$ fetal calf serum, $0.4 \mathrm{~mm}$-glutamine and penicillin and streptomycin. 
Embryonic development was observed after 4 and $20 \mathrm{~h}$ in vitro. Since no appropriate recipient was available, 4 blastocysts were transferred to two intermediate recipients which had had the uterus flushed $4 \mathrm{~h}$ before. Pregnancy examination was carried out by rectal palpation after 6 weeks.

\section{Results}

Of the 27 fixed ova, $19(70 \%)$ were penetrated by spermatozoa (Fig. 2), and no polyspermy was recorded. Of the 54 ova transferred to the oviducts of recipient heifers, $40(74 \%)$ were recovered by non-surgical means: 15 of these $(38 \%)$ were embryos at different stages, all of which developed after 4 and $20 \mathrm{~h}$ culture (Figs $3 \& 4$ ). The results from non-surgical recovery and in-vitro culture are presented in Table 1.

Each of the final recipients received 2 blastocysts by non-surgical transfer, and one was pregnant at 6 weeks, and is still pregnant at 4 months of gestation.

Table 1. Embryonic developmental stages from in-vitro matured and fertilized cattle ova incubated in vivo and then re-cultured in vitro

\begin{tabular}{|c|c|c|c|}
\hline & \multicolumn{3}{|c|}{ No. at different developmental stages: } \\
\hline & At recovery & $\begin{array}{l}\text { After culture } \\
\text { for } 4 \mathrm{~h}\end{array}$ & $\begin{array}{l}\text { After culture } \\
\text { for } 20 \mathrm{~h}\end{array}$ \\
\hline Expanded blastocyst & & $1) *$ & 1 \\
\hline Blastocyst & 1 & $5\}^{*}$ & 2 \\
\hline Early blastocyst & 1 & 3 & - \\
\hline Morula & 4 & 1 & 1 \\
\hline Early morula & 4 & - & - \\
\hline Very small morula & 5 & 5 & $5 \dagger$ \\
\hline 1-12-cell egg & 25 & 25 & 25 \\
\hline
\end{tabular}

\section{Discussion}

The rates of penetration and polyspermy were similar to those in our earlier studies (Xu \& Greve, 1988) and those reported from other groups (Parrish et al., 1986). This indicates that a reliable invitro fertilization system has been established. One of the reasons for the high success rate may be the short time interval from slaughter until oocyte aspiration $(<30 \mathrm{~min})$. It is well established that this early period is critical for subsequent germinal vesicle breakdown in vitro (Motlik et al., 1978). The good facilities for oocyte aspiration at the slaughterhouse reduces the time between when the animals are killed and the oocytes are released fron the ovaries. This might give better conditions for oocytes to mature in vitro.

Another contributing factor to the high rate of early embryonic development is the addition of serum from an oestrous cow to the oocyte maturation medium (Sanbuissho \& Threlfall, 1985). When such serum is added to the medium the most striking morphological change is a complete expansion of the cumulus cells, including the corona radiata. This feature is one of the indications of oocyte maturation in vitro (Motlík et al., 1986) and in vivo (Greve et al., 1984). Addition of granulosa cells might also enhance the subsequent developmental competence (Motlik \& Fulka, 1981; Staigmiller \& Moor, 1984).

In the present experiment we used the heifer as an intermediate recipient, and a surgical 
approach similar to that used by Trounson et al. (1977) and Shea et al. (1983). Oviducts from other species have been used as incubators (rabbit: Sirard \& Lambert, 1986; sheep: Critser et al., 1986), as it is believed that a 'block' of early cleavage, probably at the 8-16-cell stage in cattle, will occur during in-vitro culture (Eyestone \& First, 1986) unless a cell-co-culture system is used.

Although the surgical procedure is more tedious for the cow than for rabbits and sheep, this approach has some advantages: e.g. (1) the oviduct condition is likely to be more favourable to the fertilized ova than that of other species, (2) after in-vivo incubation a non-surgical approach for recovery as well as for transfer can be used. With adequate training and reasonably good surgical facilities, surgical transfer of embryos to the intermediate recipient can easily be completed within $30-50 \mathrm{~min}$.

Even though the birth of a live calf would be the ultimate proof of the efficiency of this technique, blastocyst formation is considered as a valid indication that normal oocyte maturation and fertilization have been accomplished (Moor \& Trounson, 1977). The positive pregnancy diagnosis further supports this concept.

This work was supported by grants from the Danish Agricultural and Veterinary Research Council and Leo Research Foundation.

\section{References}

Ball, G.B., Leibfried, M.L., Lenz, R.W., Ax, R.L., Bavister, B.D. \& First, N.L. (1983) Factors affecting successful in-vitro fertilization of bovine follicular oocytes. Biol. Reprod. 28, 717-725.

Brackett, G.B., Bousquet, D., Boice, M.L., Donawick, W.L., Evans, J.F. \& Dressel, M.A. (1982) Normal development following in-vitro fertilization in the cow. Biol. Reprod. 27, 147-158.

Critser, E.S., Leibfried-Rutledge, M.L., Eyestone, W.H., Northy, D.L. \& First, N.L. (1986) Acquisition of developmental competence during maturation in vitro. Theriogenology 25, 150 Abstr.

Eyestone, W.H. \& First, N.L. (1986) A study of the 8to 16-cell developmental block in bovine embryos cultured in vitro. Theriogenology 25, $152 \mathrm{Abstr}$.

Greve, T., Bousquet, D., King, W.A. \& Betteridge, K.J. (1984) In-vitro fertilization and cleavage of in-vivo matured bovine oocytes. Theriogenology 22, 151-165.

Greve, T., Xu, K.P., Callesen, H. \& Hyttel, P. (1987) Invivo development of in-vitro fertilized bovine oocytes matured in vivo versus in vitro. J. In Vitro Fert. \& Embryo Transfer (in press).

Hyttel, P., Greve, T. \& Callesen, H. (1988) Ultrastructure of in-vivo fertilization in superovulated cattle. $J$. Reprod. Fert. 82, (in press).

Moor, R.M. \& Trounson, A.O. (1977) Hormonal and follicular factors affecting maturation of sheep oocytes in vitro and their subsequent developmental capacity. J. Reprod. Fert. 49, 101-109.

Motlík, J. \& Fulka, J. (1981) Fertilization of rabbit oocytes co-cultured with granulosa cells. J. Reprod. Fert. 63, 425-429.

Motlík, J., Koefoed-Johnsen, H.H. \& Fulka, J. (1978) Breakdown of the germinal vesicle in bovine oocytes cultivated in vitro. J. exp. Zool. 205, 377-384.
Motlík, J., Fulka, J. \& Fléchon, J.-E. (1986) Changes in intercellular coupling between pig oocytes and cumulus cells during maturation in vivo and in vitro. $J$. Reprod. Fert. 76, 31-37.

Parrish, J.J., Susko-Parrish, J.L., Leibfried-Rutledge, M.L., Critser, E.S., Eyestone, W.H. \& First, N.L. (1986) Bovine in-vitro fertilization with frozen thawed semen. Theriogenology 25, 591-600.

Sanbuissho, A. \& Threlfall, W.R. (1985) The effects of estrous cow serum on the maturation and fertilization of the bovine follicular oocytes in vitro. Theriogenology 23, 226 Abstr.

Shea, B.F., Janzen, R.E. \& McAlister, R. (1983) Recovery and fertilization of bovine follicular oocytes. Theriogenology 19, 385-390.

Sirard, M.A. \& Lambert, R.D. (1986) Birth of calves after in-vitro fertilization using laparoscopy and rabbit oviduct incubation of zygotes. Vet. Rec. 119, 167-169.

Staigmiller, R.B. \& Moor, R.M. (1984) Effect of follicle cells on the maturation and developmental competence of ovine oocytes matured outside the follicle. Gamete Res. 9, 221-229.

Trounson, A.O., Willadsen, S.M. \& Rowson, L.E.A. (1977) Fertilization and development capability of bovine follicular oocytes matured in vitro and transferred to the oviducts of rabbits and cows. J. Reprod. Fert. 51, 321-327.

Xu, K.P. \& Greve, T. (1988) A detailed analysis of early events during in-vitro fertilization of bovine follicular oocytes. J. Reprod. Fert. (in press). 